\title{
Re-imagining the practices of town, social and community planning in Australia: Opportunities for planning in neoliberal policy settings
}

Authors:

Dr Lynda Shevellar, Lecturer, School of Social Science, The University of Queensland, Brisbane, Australia.

Laurel Johnson, Associate Lecturer, School of Geography, Planning and Environmental Management, The University of Queensland, Brisbane, Australia.

Associate Professor Kristen Lyons, School of Social Science, The University of Queensland, Brisbane, Australia.

Publication details: This manuscript has been accepted for publication in Australian Planner. Acceptance Date: May 15, 2015.

To cite:

Shevellar, L., Johnson, L. \& Lyons, K. (in press). Re-imagining the practices of town, social and community planning in Australia: Opportunities for planning in neoliberal policy settings. Australian Planner.

Corresponding author:

Dr Lynda Shevellar

Lecturer, Community Development

School of Social Science

The University of Queensland, Qld, 4072, Australia

Tel. +6173365 4927

Fax. +61733651544

Email: 1.shevellar@uq.edu.au

Statement of originality:

This manuscript has not been published elsewhere and has not been submitted simultaneously for publication elsewhere. 


\begin{abstract}
Town, social and community planning are among a broad suite of planning pathways widely understood as aiming to ensure development and associated social change is in the interest of the 'public good'. While there are convergences in these planning approaches, they also diverge in multiple ways, including in understandings of who legitimate players are, and how planning gives voice to the knowledge and interests of such players. In this paper we map the similarities and differences of these planning approaches in the Australian context, considering the philosophical and praxis underpinnings of each approach. While divergence in the knowledge, mandate and institutional legitimacy of each approach is highlighted, the extent to which they are unified in a commitment to people and ecology is also considered. Given the constraints imposed by neoliberal ideology, this paper argues there is some urgency to reposition planning approaches. We argue that converging foundational interests need to be considered and attention paid to the energetic community-based coalitions that are forming to empower communities in planning. This will ensure the continued relevance of all three planning approaches in the creation of a fair and environmentally responsible Australia - historically core mandates for all planning praxis.
\end{abstract}

\title{
Keywords
}

Australia, Community Planning, Neoliberalism, Planning, Public Interest, Social Planning, Town Planning, Urban Planning 


\section{Introduction}

'So a town planner, a social planner and a community planner walk into a bar...'

What sounds like the start of a bad joke was actually the beginning of an endeavour to draw some distinctions between three overlapping professional approaches: town planning, social planning and community planning. Despite co-habiting a subject area loosely defined as 'planning' we are informed by different disciplines and professional backgrounds. Professional discourses use concepts from town, social and/or community planning interchangeably and methods are often shared. Driven by a desire to distinguish the work we do, and the practical need to guard against excessive overlap in our teaching, we have engaged in a series of deliberative conversations over three years. This resultant article reflects these conversations by critically examining the intersections and boundaries of our respective disciplines. We seek to understand how these three areas circulate, collaborate and sometimes compete for space within the planning discourse.

The act of drawing boundaries is by its very nature, limited and artificial. However we have attempted to do so here to highlight the varying approaches and intents within planning. There are numerous other planning approaches that could be considered (environmental, cultural, and infrastructure planning just to name a few). We also recognise that in situ, the nature of planning is further mediated by practitioners, who bring with them their own personal and professional understanding. We therefore acknowledge the limitations of the discussion that follows. However, we assert that this discussion is helpful in teasing out common values that can provide an affirming basis for teaching, research and practice. 
This article connects to important conversations in the planning literature. These conversations are motivated by a sense of urgency for the planning project to confront issues of social polarisation, market instability and environmental degradation. The complexity of this mission requires reflection on the role of planning in the face of these uncertainties. Healey (1997, 2012), Sandercock (2012), Gleeson and Steele (2010), Gleeson (2014), Friedmann (2011) and many others are alerting the planning community to the possible pathways for planning and planners. We aspire to contribute to this conversation through our observations of town, social and community planning theory and practice and the relationships between them.

This discussion is deliberately located in the context of Australia, as a shared site of practice for all three authors. More importantly, Australia is a dramatically shifting and increasingly complex site for planning, particularly given its sparse population yet rapid urbanisation, its location in the geographical south but the ideological, political and cultural north, and the pressures for (what at least some powerful actors believe to be limitless) growth, in an increasingly fragile ecology, as articulated at the recent 2014 G20i Summit.

The article proceeds by firstly providing an historical foundation for the broad professional project of planning, before examining the philosophy and praxis of town planning, social planning and community planning in turn. Alongside these observations we also consider the Australian political milieu. We argue that in the context of a neoliberal and corporatist government, demonstrated in the ongoing withdrawal of state-based planning for people and the softening of legislation that drives such planning, there is a need to find new ways to assert processes that ensure people, place, livelihoods and ecologies matter in planning in Australia. We conclude by arguing that consideration of the converging foundational interests of each of the planning disciplines we have scrutinised provides a framework for both 
empowering communities in planning processes, as well as ensuring the on-going relevance and effectiveness of these planning approaches.

\section{Planning: An Historical Perspective}

Sandercock and Forsyth note that 'there is little agreement within planning as to what constitutes planning theory' $(1992,49)$. It is therefore useful to turn to the broader history of modern planning as a means of identifying some common territory. While we acknowledge that there is evidence of planned settlement for human habitat as long ago as 2600BC (Mohenjo-Daro has been dated to this era), our focus is the recent history of urban planning that is foundational to modern understandings and practice. In this context, planning can be broadly conceptualised as an historical legacy of the Enlightenment (Friedmann, 2011). The Enlightenment pursued scientific progress, and sought to extract the thinking behind this and apply it to social and political life. It created movement from a dominant religious worldview, to a highly reductionist mechanistic worldview that embraced systematic doubt, empirical and sensory verification, and the abstraction of human knowledge into separate sciences (Gay 1996; Israel 2009). On the basis of this reductive logic, the world was made knowable via metrics and measures (Laszlo 1996).

This laid foundations for the industrial revolution, which in turn led to a range of significant changes to the way societies were organised, including large scale manufacturing and the development of factories, mass immigration and movements into the cities. By the late nineteenth century and early twentieth century, the speed and magnitude of these changes resulted in cities facing physical degradation and functional chaos. There were public health issues, including infectious diseases, poor sanitation, overcrowding and public nuisances (such as laundry building fires). Institutionalised planning, and in particular urban planning, 
emerged as a response to this morass. Planners joined with the industrial philanthropists to develop model towns, demonstrating the value of separating incompatible land uses and coordinating infrastructure for functional efficiency. Planning forefathers such as Howard and Le Corbusier sought to ensure that people, and their quality of life, were an integral part of development (Fishman, 2003), with planning emerging as a professional practice to guide a range of reforms. These included instituting building and housing codes to improve urban slums, the imposition of public health regulations, and creation of public parks and gardens. Such reforms attended to how land was used to try and create order among the random chaos of the city.

In the early 1900s the European planners began developing 'master plans' for cities, reimagining the use of public space. Key buildings and civic and capitalist infrastructure were located around public spaces and transport infrastructure. During the 1920s-1950s and the uptake of the automobile, attention shifted to highways and sub-urban subdivisions, moving cities beyond their fixed railway corridors. After World War II visions of the 'good life' emerged in new development configurations (see Mackay, 2013). The new town movement conceived variable ways to address the same dilemma; how to create environments that democratically and fairly balanced the needs of residents and economy. Thus the modern idea of planning - the context for our contemporary analysis - is centrally linked to concepts of democracy and progress (Friedmann, 2011). It centres on the challenge of finding ways in which citizens, through acting together, can manage their collective concerns, with respect to the sharing of space and time (Healey, 1993). It rests on an assumption that reality can be understood, controlled and perfected. Underpinning planning is the idea that social problems can be tamed and humanity liberated from the restraints of scarcity and greed and that the externalities of modern capitalism such as pollution, overcrowding and the disconnection between community and nature can be addressed through processes and plans. 
What this historical overview demonstrates is that contemporary urban planning is essentially a modernist project. It harnessed systematised social scientific knowledge and techniques to manage collective affairs in a democratic society. It required a procedural view which presented planning as a progressive force for economic and social development in a world where democracy and capitalism were seen to co-exist in comfortable consensus (Healey 1993, 234). Planning was justified as an intervention in the private market in pursuit of the 'public interest'. However, the public interest was determined by politicians and town planning practitioners as they defined the public and the scope of their interests.

As a result, the modernist planning project began to unravel in the 1970s and 1980s. Criticisms of this project were emerging as it was recognised that democratic intention may be subverted for other purposes. Town planning, it was argued, put the needs of capital (through economic development and the implicit opportunities for land and property markets created by planning regimes) before citizens and the environment (Harvey 2001; Jacobs 1964). In other words, the concept of planning shifted from a benign or even helpful activity to control chaos and disorder, reduce poverty and improve health, to an exercise of power.

In response to such critiques, the 1980s saw the proliferation of grassroots planning approaches; including those that centralised planning for people by including local, or situated knowledges, into the planning process. A number of participatory techniques proliferated to engage local communities in planning interventions. This trend was commensurate with the broader participatory turn in many parts of the so-called developed world. The work of Chambers (1983) is seminal, offering a range of participatory methods that planners can adopt so as to learn from those 'on the ground'. Others similarly argued for the importance of participatory approaches for local capacity building, as well as in assisting to build social capital; which many argue is vital to ensuring trust and community resilience, and effective long term and sustainable planning interventions (Cox 2000; Putnam 1993). 
These participatory approaches were not, however, devoid of power, with questions and concerns also raised about whose interests might be included, while others excluded, in these dialogic and participatory planning initiatives (Dryzek 2009).

While these grassroots and participatory planning approaches often worked on the assumption that the inclusion of local people in planning processes would deliver outcomes that addressed local needs, others offered a more radical critique. As Healey (1993) notes, a more fundamental challenge emerged through the critique of scientific reason itself. The ideas of German critical theorists and French deconstructionists challenged the dominance of reason. Reason, understood as logic coupled with scientifically-constructed empirical knowledge, was unveiled as having achieved hegemonic power over other ways of being and knowing, crowding out moral, cultural and aesthetic discourses.

Evidence of the authority of scientific reason seemed to be everywhere, from the disaster of high-rise tower blocks for the poor to the dominance of economic criteria justifying road projects. Zones are categorised in ways that serve the interests of large industrial companies and those working in them, but not necessarily minority groups, including the interests of women, children, the elderly and disabled, as well as cultural groups. This challenge to systematised reason, and with it, to the planning enterprise, strikes at the heart of the project of modernity.

While this postmodern critique suggests a departure from old thinking patterns, Skolimowski argues that the present environment is much more complex:

The old is crumbling and the new has not yet sufficiently articulated itself...Tired of the staleness of the religious mode of life, the seventeenth century rediscovered the physical. Tired of the triviality of the material mode of life, we are rediscovering the spiritual (1994, xiv). 
What has emerged in this space is planning as a linear, modernist process - as represented by current legislation and planning practice, alongside a critique of planning as an exercise of power. While this critique has very powerfully shifted planning discourse in academic realms, the outcomes for planning practice and the physical and social environment are scant. The reliance in planning practice on more and better predictive and measurement tools is underpinned by a belief that the development of people and environments is linear and unsurprising. This contrasts with academic deliberation about power relations in shaping cities and emergent knowledge of the impacts of unexpected environmental phenomenon on people and cities. This vacillation between the academic critique and the practice context has implications for each of the three planning approaches. Before examining these approaches in more detail it is important to contextualise our discussion in the changing place of planning in Australia, with particular reference to the state of Queensland.

\section{The Changing Place of Planning in Australia}

There is a long history of formal planning Australia's urban, regional and rural spaces. Since invasion and colonisation, these forms of planning have comprised a mix of ad hoc, incremental and interventionist approaches, often linked to the politics of the day. Given the concentration of Australia's population in coastal and urban settings, urban planning has dominated Australian planning practice.

In recent decades, effective planning in Australia can be seen as having been shaped and constrained by a number of factors. Of particular interest to our analysis of planning in this paper is the growing confluence of public sector and commercial interests. Demonstrating this in their analysis of south east Queensland planning, Gleeson and Steele (2010) describe the 'TransApex' scheme; an infrastructure initiative including (toll) road, tunnel and bridge projects, with outcomes that have, not unexpectedly, encouraged private car use rather than 
public transport. Gleeson and Steele see this as a symptom of privatised interests driving planning processes, above social or ecological considerations. This is also an example of the high priority given to city-based infrastructure projects that serve (often private interest led) economic development objectives. There are other tensions in planning, which are emerging at both the state and federal levels. These include the growing political momentum to cut 'red tape', referring to the policies and procedures that are framed by some stakeholders as slowing regional and national development. Alongside this, the strong commitment to support on-going expansion of Australia's extractive industries is demonstrated in recent calls to reduce 'green tape', referring to national and state environmental regulations, in ways that facilitate mining industry expansion (Business Council of Australia 2012; ABC 2013). This has been matched by political rhetoric that describes deliberate and consultative planning processes as slowing down positive development outcomes for states and the nation. These reductions in government regulations are being met with strong community responses, with insights that can inform diverse planning approaches. This is a theme we will return to later in this paper.

It is against this recent backdrop of neoliberal policies and processes, and community responses and resistance that we turn now to examine the contested nature of town, social and community planning in Australia.

\section{Town Planning}

Turning to the first planning approach, town planning, it was noted earlier that modern town planning practice has noble origins as a technical vehicle for the pursuit of a better life in the city. An ongoing dilemma for town planning is that it oscillates between a radical and transformative intervention and a way to maintain a city's function (Friedmann in Healey 
2012, 214). Yet, no matter where the town planning practitioner sits on this spectrum, from intervention to technical functionality, there is a shared belief that community members lack the planning literacy of the town planner. The town planner is the expert in shaping space.

Rationality is privileged in town planning practice as it delivers a level of assurance to practitioners, political decision makers and arguably, to communities. One of the reasons for this observance of rationality could be that, unlike social and community planning, town planning is a legislated, regulatory practice. Town planning is an intervention in the private property market and thereby in the property rights of land owners and land users. To justify intervention in the market, town planning decisions must be legitimate and reasonable and be arguable in law. They should have a basis in empirical 'facts'. Town planning is underpinned by evidence derived from quantified data and predictive environmental and social modelling tools and techniques. These predictive tools are based on inputs derived from a familiar past and the outputs of the models are a certain future. Within this expert frame, the knowledge that resides in communities is not a necessary input to plan making. This has implications for the value and role of participatory practice in town planning.

Two key values that are codified in law and that underpin contemporary Australian town planning practice relate to the right of communities to participate in planning and the pursuit of ecologically sustainable development. These values have been critical elements influencing Australian town planning practice - although in the current political landscape, they are subject to review. The National planning reform agenda and the success of conservative political parties at the State level have resulted in reviews of town planning legislation and planning policy.

The reform agenda is typified by the Commonwealth Organisation of Australian Governments' (COAG) The National Objective and Criteria for Future Planning of Capital 
Cities (2009) framework (Ruming et al, 2014, 114). While that document promotes the objective to 'ensure Australian cities are globally competitive, productive, sustainable, liveable and socially inclusive and are well placed to meet future challenges and growth' $(2009,20)$, the ways to achieve this objective is silent on social and environmental initiatives. In fact, the criteria that are identified as measures for Capital city strategic planning systems to achieve the objective do not include social wellbeing or environmental protection activities. Rather, the nine criteria emphasise procedural matters such as integrated planning and a hierarchy of plans as well as providing for economic infrastructure. A significant criterion is to '.. provide an effective framework for private sector investment and innovation' (COAG, 2009). As outlined above, the explicit message is that the purpose of town planning in Australia's cities is to promote economic growth through infrastructure development and private sector investment.. The implicit message is that social wellbeing and environmental protection objectives are not as important as economic development. The repeal and redrafting of town planning and environmental protection legislation and policies have the potential to compromise the achievement of the environmental protection and the social wellbeing objectives of ecologically sustainable development as these outcome areas are weakened in regulatory practice. ${ }^{\mathrm{ii}}$ The preference for an unfettered private property market and the shifts in State level planning law, policy and resources serve to reduce Australian town planners to development enablers.

Despite this negative domestic trend (at least in social and ecological terms), there is emergent global interest in a revised town planning practice as a vehicle for improving the lives of urban communities in developing cities. The UN Habitat Global Report on Human Settlements $(2009,2011)$ identifies town (urban) planning as a critical practice for developing cities to address the impacts of climate change, food security, housing provision, social equity and infrastructure coordination. Town planning for this purpose is considered a form of 
governance, a collective action to redress environmental and social adversity (UN Habitat 2009, 212). The UN Habitat perceives town planning as explicitly guided by values to deliver more just and environmentally sustainable development. Town planning will be guided by an explicit vision and value set in pursuit of the sustainable city. The sustainable city will be inclusive, productive and equitable and the urban planner will work with communities and stakeholders to develop integrated plans to achieve sustainable cities. In this sense, the global version of town planning practice is consistent with the earliest aspiration of town planning as an intervention in the property market to shape cities in the public interest and for the public good.

With this as background, we posit that town planning stands at a crossroads. If town planning practice is interventionist and explicitly value driven for the public good, then its alignment with both social and community planning might be seen as assisting to further strengthen the achievement of such goals. The social and community planning discipline areas can provide the town planner with insight into community structures and processes and assistance with broad based community engagement and the translation of local knowledge. However, if town planning is a simple technical practice to maintain and enhance economic growth through development - an outcome of its historical origins outlined earlier in this paper then there is less opportunity for an interface between the three approaches. To continue this analysis, we now turn to the second related discipline of social planning.

\section{Social Planning}

Similar to town planning, social planning has foundational values that articulate a commitment to the public good. There is a shared concern to design and undertake largely market-based interventions that improve social and to an extent, environmental outcomes. In this sense, both town and social planning share a commitment to bring people into the 
planning process, with outcomes that will generate benefits for communities of interest. The point of difference is the extent to which each approach appreciates the diversity and complexity of 'the people', and the interplay of relational power in communities. The range of tools and techniques utilised by each approach is a reflection of the relative insights into the interplay of power that determines who will be involved and how they will be engaged in planning.

Social transformation, redistribution and participation are widely recognised as both central principles and goals of the social planning project (Bromley 2003). With a philosophical commitment to building people into the planning process, and burgeoning as a profession in its own right over the last few decades - including accreditation and formal recognition as a distinct arena by the Planning Institute of Australia - social planning is based upon approaches and methods aimed at measuring social gaps, needs and assets, and incorporating these into decision making and planning processes. In the current context of migration, postcolonisation and the rise of social movements (amongst other factors) - or what Sandercock (2012) describes as a cultural politics of difference - the importance of social planning has never been more important.

Social planning, like town planning, is grounded in the modernist ontology outlined above. In its goal to render the social world knowable, the social planners' toolkit includes methods such as gap analysis, needs assessment, community profiling and visioning, and stakeholder analysis. Each of these, in different ways, offers a set of techniques to measure and therefore 'know' the social world. The outcome has been to provide metrics that can be documented over time, thereby making visible social change on the basis of baseline information and data. And there is growing evidence that social planning delivers on this task, with a recent study by Baum et al. (2011) demonstrating the social capital, and associated positive health outcomes, associated with effective social planning. Where social planning departs from the 
objective stance of town planning practice is in attempting to balance broader industry and economic priorities with social knowledge - including local people's hopes, needs and aspirations.

Yet the social planning project has also been criticised as complicit in its institutionalisation of a reductive logic that assumes the social world is knowable, and that such knowledge can simply be added into the broader planning process, thereby delivering broadly acceptable outcomes. In this context, social planning has also faced critique for being implicated in processes that engineer certain outcomes, including those that serve the interests of their employers (for example private sector land and housing developers, mining sector interests etc.), rather than broad-based community interests (Bromley, 2003). The location of social planning as part of processes for planning within broader market based forms of development has also faced critique for overlooking the diversity of 'beyond the market' or 'outside the market' development interventions to which communities are actively engaged, including alternative and diverse economies (see Gibson-Graham, Cameron and Healy, 2013).

A mediating factor in examining the place and outcomes of social planning also relates to the location, or positionality of planners. The politics, tactical and strategic intentof plannersmay all shape the goals and outcomes of social planning processes. While this aspiration presents its own challenges, it also extends the planning purview. Through this lens, social planning praxis is able to bring certain worlds into being (Cameron and Wright, 2013). This poststructuralist view sees social planners' performativity as intervening in the planning process, including in ways that generate emancipatory and transformative change work (Sandercock 2004). Through their praxis, social planners can expose alternative geographies of possibility, including shifting the focus of planning from the market, capitalist integration and infrastructure for development, to consider the diverse economies in which people are engaged. Extending understandings of the performative role of social planners, Steele (2014) 
conceives of planning as border work; describing planners as actively engaged in unsettling and disrupting traditional borders (including psychological, social, economic and material borders) as part of the transformatory planning agenda.

Sandercock further articulates this postmodern tradition; describing an 'audacious, creative and therapeutic' agenda for social planners so as to enable positive change in the communities they work (2004, 133). Poon, Button, and Nijkamp (2006) and Sarkissian et al (2006) add to this transformative agenda, highlighting the need to frame social planning praxis within a broader agenda of sustainable development and ecologically inspired principles. These calls have resonance with broader trends in planning theory which recognise the need to plan with ecological limits in mind (although practice and policy often fall short on this goal) (Byrne, Sipe and Dodson 2014; Lowe 2010). This ongoing tension between a postmodernist planning agenda, and planning practice is seen even more starkly in the third planning approach, that of community planning.

\section{Community Planning}

If town and social planning are contested projects, then community planning invites an even greater degree of ambiguity and dissent. Politically, community planning can be seen as part of the global trend of democratisation, steeped in the belief that people have a right to participate in the decisions that affect their lives. This agenda places it clearly in the realm of political science and the new politics of governance, deliberative democracy and dialogical and deliberative processes (Makau and Marty, 2013). The shifting intent of planning legislation (as discussed earlier) influences the willingness of authorities to engage with the community, as well as the scope and authenticity of consultative processes. Community planning can therefore be seen firstly as a vehicle for community engagement, consultation 
and management by authorities within the broader planning agenda. It varies from being conservative to reformist in scope.

Secondly, emerging from community development, community planning can be understood as providing alternatives to the less humanist interventions of the market, the global economy, bureaucracy, professionals and the welfare state (Ife 2013). It strengthens the capacity of people to define, analyse and solve the issues facing them at local levels (see for example, Hope and Timmel 2014). It emphasises processes of participation and connection, rather than engagement and consultation, and thus constructs an alternative space, rather than serving other planning agendas. This moves the idea of planning away from the physical planning territory and into an existential realm more focused upon a sense of belonging.

Thirdly, emerging from the space of contentious politics, community planning can be seen as a force to resist state and private sector interventions. Utilising the analysis and strategies of nonviolent intervention, community organising, campaigning and mobilising, resistance and social movements, it holds a radical agenda for change, and often acts against the vested interest of the corporate sector and the State (Sharp, 2010). Naming this the "social mobilisation tradition of planning', $(2011,60)$, Friedmann observes that this is not a new advent; the counter-tradition to state-centric planning has accompanied the evolution of industrial capitalism from the beginning.

This multidisciplinary background helps explain the ambiguity of community planning. It also shows why it would be wrong to assume that the seemingly benign language of “community" is any less an act of power. Current community planning technologies (from participatory rural appraisal technologies such as mapping, to popularised public participation processes such as World Cafes and Open Space events) may appear less intrusive or outwardly controlling than social processes such as SIAs and LogFrame analysis. But as 
Nikolas Rose (1999) asserts, in the institution of "community", a whole sector is constructed whose forces can be mobilised, enrolled, and deployed to encourage active practices of selfmanagement and identity construction, personal ethics and collective allegiances. For example, in their study of regional Australia, Cheshire and Lawrence (2005) demonstrate how the new structures of government and strategies promoting "self-help" and 'selfreliance' link the spirit of community and rural ideologies to the values and behavioural frameworks of neoliberalism to re-establish and reinforce hegemonic political objectives.

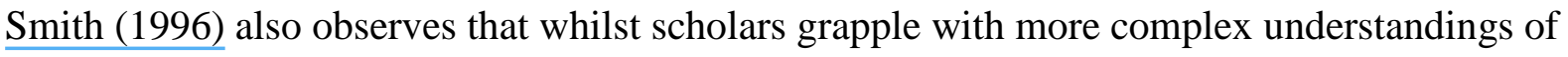
community, the 'myth' of community remains powerfully established in everyday thinking as an ideological control mechanism and as a utopian vision. In her analysis of the 'spacialities' of community, Rose contends that imagining community as a three-dimensional space, with a centre and a margin, extracts violent costs and fundamentally structures exclusion. She argues that current conceptions of community are complicit with 'colonialism, the phallocentric constitution of sexual difference, and the bourgeois construction of classed difference' (1997, 12). Such spaces, she argues, are constitutive of 'essentialised fantasies of identity' (12). In response, Burkett (2001) calls for a postmodernist perspective which gives rise to a view of community as a 'processual creation' (237) rather than a fixed description:

Thus, community is not necessarily a site at which practice occurs, rather, it becomes a frame of reference which is neither map nor territory, but an orientation which emphasizes the rationality and contextuality of human practice, in all its messiness (239).

This re-imagined community calls for a spatiality which can acknowledge partial and changing membership, contingent insiderness, uncertainty, loss, gaps, interruptions and absence (Rose 1997). Such an understanding moves beyond simple process approaches to 
planning to consider how systems of relationships shape a particular context. However this dynamic, problematised and much more uncertain understanding of community runs counter to the popular territorial conceptions of community in town planning. The next section takes up the theme of complexity in comparing all three planning approaches, with a particular focus on the Australian planning landscape.

\section{Surveying the Planning Practice Landscape}

The analyses above speak to both the conservative and radical intents of each of the three planning approaches outlined in this paper. In analysing the historical, philosophical and praxis underpinnings of town, social and community planning, what becomes evident is that all three hold consideration of people, and, to varying degrees, inclusion of their physical, social and metaphysical contexts. In doing so, town, social and community planning all conform to Healey's construction of planning as being about 'managing our co-existence in a shared space' (1997, 3). All three approaches espouse a belief in the public good. But at the level of practice, all three planning disciplines are also influenced by how the public good is defined and in whose interests it is articulated. Thus, what these planning approaches also share is their function as an exercise of power.

For town planners this power is manifest in a dominant truth regime that privileges objective, rational, and technical constructions of knowledge, demonstrating legacies from the earlier planning as modernist project. Both town and social planners' power is also exercised through socially sanctioned practices of legislation, professionalisation, and accreditation. For community planners - particularly those located in community development and nonviolent traditions - power emerges through the mandate of the people and the idea of collective voice and action. Knowledge is constructed not via universalist principles or legislation, but in 
humanist understandings. Figure 1 provides one possible depiction of these spaces of difference and overlap.

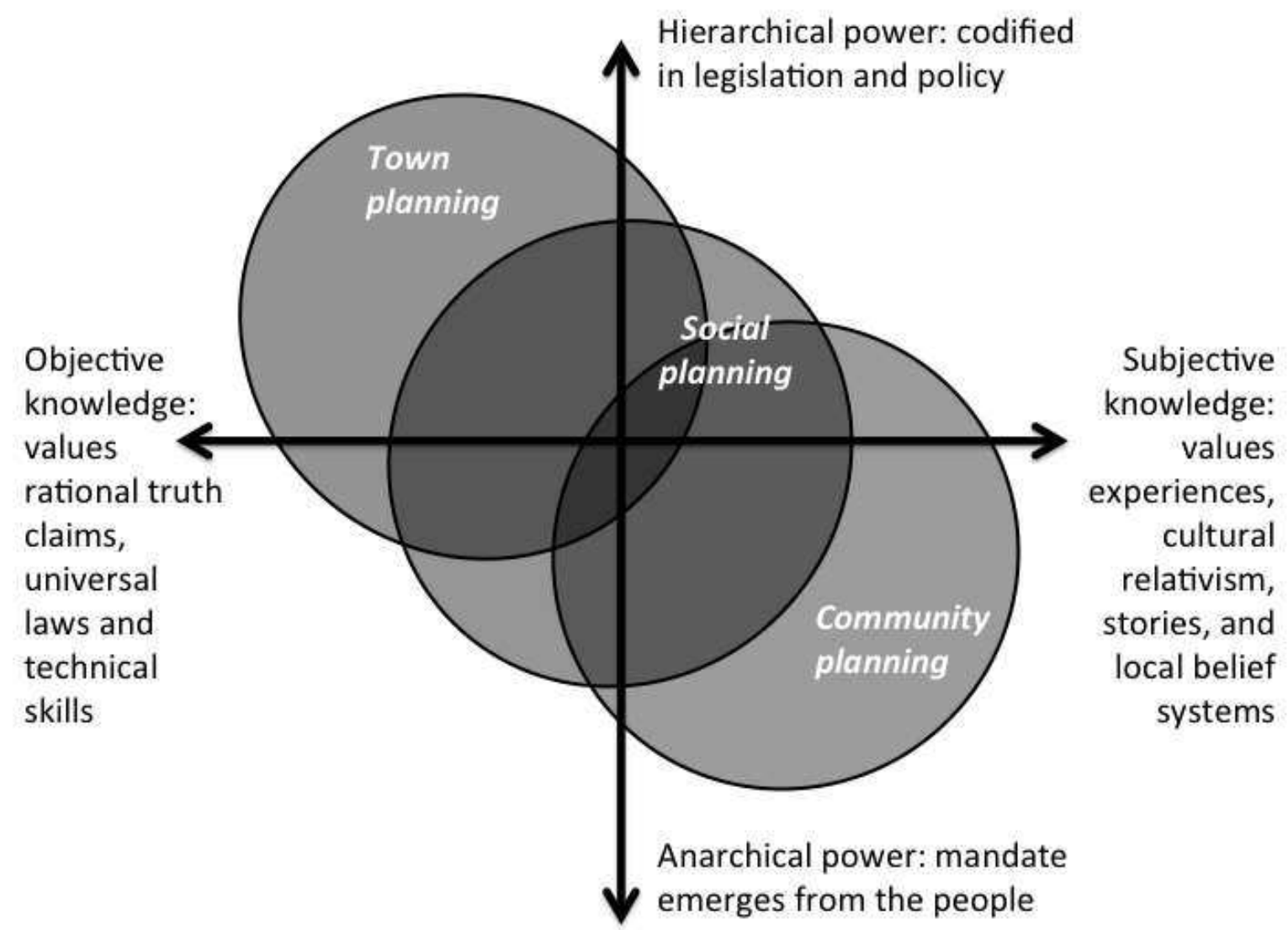

Figure 1: The planning practice landscape

What this figure demonstrates is that town, social and community planning are not mutually exclusive. There is overlap in history and theory, and, as flagged earlier, many of the methods are shared. However where they do differ is in the types of knowledge that are privileged and in their mandate for action.

What the three approaches also share is the influence of the current neoliberal turn in planning. Demonstrating this, town planning has been impacted by reforms at both the National and State levels. Such reforms have been driven by the promotion of a streamlined development assessment, accompanied by strategic visioning for Australia's cities. Yet these objectives are sometimes contrary, as communities struggle to trust participatory strategic 
visioning exercises when their rights at development assessment (where the visions are realised) are removed. The 'contradictory ambitions' for city planning of strategic city visions, coupled with regulatory reform for streamlined development assessment, typify both the Labor and Liberal Party planning reforms (Ruming et al 2014, 109). In this context, town planning is suffering a crisis of public trust (Stain and Tait, 2007), the outcome of which is driving many communities to organise to write their own plans and scrutinise development decisions - a theme we will take up next.

Meanwhile, the neoliberal project has also had significant impacts for social planning, including reduced funding, a weakening legislation, and an eroding regulatory base. This joint erosion of both financial and regulatory means for effective social planning has occurred at the same time as private sector actors have increasingly come to dominate the social planning space. For example, private developers have increasingly come to employ social planners to assess and implement social plans, including scrutinising their own best practice; reflecting the private led audit culture evident across a range of sectors and industries. As a part of these processes of corporatisation, the legitimacy of social planning practice is eroded, as its purpose can be seen as being reduced to the technical assessment of development projects.

Community planning has similarly been weakened by the erosion of community rights in development assessment, as well as the general loss of government funding for community development and community organisation, as well as social support services. This is overlaid by an appropriation of the language of community development to serve state agendas.

Despite the effects of neoliberalism on each of the three realms of practice, there is debate about whether the planning glass is half empty or half full. That is to say, we think it remains to be seen, in the context of neoliberal policy and processes outlined in this paper, the extent 
to which constraints currently imposed upon all three forms of planning will leave room for effective social and environmental change work to arise from planning practice. An activity that inspires hope for a revitalised and responsive practice is resident activism in planning and development. Whether it is a reaction to the weakening of public scrutiny of development proposals at development assessment or a desire for a more sophisticated and comprehensive analysis of planning and development decisions, or some other driver, community mobilisation in planning and development in Australia is undeniable as our final section now explains.

\section{Community Organisation and Action}

Collective action through community organisation in Australia has been effective in disrupting the planning reform agenda. The action of community organisations has stopped many developments at the development assessment stage, despite the drive to streamline assessment by removing the rights of communities to 'have their say' on specific development proposals. However this is not simply a negative or resistant force, but as recent events in West End, Brisbane demonstrate, it is also a creative endeavour in which communities are rewriting themselves back into the planning process. In doing so they are unsettling the idea that economic growth is the primary objective of planning.

The collective action of communities is a force that challenges town planning to pay attention to the urban power critiques and insights of community planning. If town planning is to address the crisis of community trust in planning (Swain and Tait, 2007) then the discipline must turn to the theories and practices of community planning. 
Communities have the ability to undertake analysis and develop local solutions to urban problems and development challenges. Each Australian city and many regional areas have community organisations that form coalitions and campaign against development, including resource development. These communities do not adhere to restrictive and disciplined consultation processes, but rather effectively campaign against planning decisions, development proposals and plans. The Lock the Gate movement has been successful in both slowing the expansion of the coal seam gas industry, as well as drawing wider community attention to the potential risks of resource development, particularly coal seam gas exploration and development. The proliferation of yellow triangular signs declaring 'lock the gate' on farm gates throughout regional Australia is evidence of the support for this local response to a major development sector with substantial government support (Hutton, 2012).

In the cities, the urban densification policy of State governments has also encountered resistance in its implementation in every major Australian city. There are numerous examples of city-based resident organisations including Save our Suburbs (Sydney and Melbourne), Residents Against Inappropriate Development (Melbourne), West End Community Association (Brisbane), and many others. The Brisbane Residents United is a coalition of 44 organisations. The aim of that grouping is to 'represent Brisbane and surrounding district residents and provide them with a united voice (and through which local resident groups can have a voice) to Council, State and Federal Governments on matters pertaining to urban planning and development' (Brisbane Residents United). The evidence of resident resistance to unfettered development is clear. What is not clear is how the three planning approaches will respond to these emerging dynamics and tensions.

\section{Conclusions}


Reflections on the planning practice landscape indicate that the current planning reform agenda has implications for town planning, social planning and community planning. A principle of this reform agenda is that communities can 'have their say' at the strategic planning stage, when plans are developed. Yet in the neoliberal context we describe, community rights at the development assessment stage have been eroded. This reformist agenda is contrary in that 'up front' community visioning is paired with development assessment reform that locks communities and interest groups out of the implementation stage of plans. This principle is based in a belief that community interests somehow work against achieving the economic prosperity goals of planning. It is also based upon the false assumption that achieving economic growth will somehow 'trickle down' to affect broader positive social and environmental change and that the community will remain passive in the face of plans and specific public investment that promotes the city as Australia's economic engine.

Encouraged by both Labor and Liberal Federal Governments, the Australian city is promoted as the economic engine of Australia. The Federal Government uses major infrastructure funding to oil the city and incentivise the State Governments to prioritise economic development as a critical driver for urban planning activity. These policies and practices move town planning away from social justice and ecological sustainability objectives. Yet at the same time, and in response to this meta-narrative at the Federal government level to streamline the planning system for economic growth, there is local community activity in the tradition of collective resistance. Indeed, our paper has demonstrated that the activities of mobilised and organised communities in Australia are an effective force in disrupting the implementation of strategic plans for economic development.

Such forms of resistance and disruption point to the limits of reductionist and simple views of community, environment and economy as separate and somehow in competition - a legacy of 
the modernist planning project - in delivering sustained growth in our cities. It is accepted that our cities are undergoing environmental, social and economic transformation. There is unprecedented change resulting from climate change, social polarisation, demographic change and global economic shifts. In this context, there is an urgency to recalibrate town planning and development as intentional vehicles to fair, environmentally responsive Australian cities and regions. More importantly, we argue, there is a need to reposition social and community planning to promote the traditions of collective community action and community development.

On the basis of our analysis of these three disciplines of planning, we conclude by arguing that there is value in considering their converging interests; including harnessing the particular methodological and value based strengths of each discipline of practice. In disrupting the traditional borders that have at least in part separated these disciplines, come new opportunities to learn and grow the professions in ways that may enable us to address the wicked planning problems of our times. Such convergences may also ensure the continued relevance and effectiveness of each of the three planning approaches scrutinised in this paper. Surely the current crisis of social, environmental and economic uncertainty provides just the incentive needed for a reimagined planning with a determination to deliver socially just, green and liveable places?

\section{Acknowledgements}

We would like to thank members of the UQ Housing and Urban Studies Network for their feedback on an earlier draft of this article.

\section{References}


ABC. 2013. Red Tape Limits Oil and Gas Industry Productivity. ABC News. Accessed May 27. http://www.abc.net.au/news/2013-05-27/red-tape-limiting-oil-and-gas-industryproductivity/4714308

Baum, F., C. Putland, C. MacDougall, and A. Ziersch. 2011. "Differing Levels of Social Capital and Mental Health in Suburban Communities in Australia: Did Social Planning Contribute to the Difference?" Urban Policy and Research 29 (1): 37-57.

Brisbane Residents United at http://www.brisbaneresidentsunited.org.au/category/storytype/aboutus, accessed 29 March 2015

Bromley, R. 2003. "Social Planning: Past, Present, and Future.” Journal of International Development, 15: 819-830.

Burkett, I. 2001. "Traversing the Swampy Terrain Of Postmodern Communities: Towards Theoretical Revisionings Of Community Development." European Journal of Social Work, 4 (3): 223-246.

Business Council of Australia. 2012. Discussion Paper for the COAG Business Advisory Forum. (April).

Byrne, J., N. Sipe, and J. Dodson. 2014. Australian Environmental Planning. Challenges and Future Prospects. Oxon: Routledge.

Cameron, J. and S. Wright. 2013. "Researching Diverse Food Initiatives: From Backyard and Community Gardens to International Markets.” Local Environment 19 (1): 1-9.

Chambers, R. 1983. Rural Development: Putting the Last First. New York, NY: Routledge.

Cheshire, L. and G. Lawrence. 2005. "Neoliberalism, Individualisation and Community:

Regional Restructuring in Australia.” Social Identities 11(5): 435-445. 
Cox, Eva. 2000. “Creating a More Civil Society: Community Level Indicators of Social Capital.” Just Policy: A Journal of Australian Policy 19 (20): 100-107.

Draft Queensland Planning and Development Bill 2014. Accessed September 20.

http://www.dsdip.qld.gov.au/resources/bill/draft-planning-and-development-bill.pdf

Dryzek, J. 2009. "Democratisation as Deliberative Capacity Building." Comparative Political Studies 42 (11): 1379-1402.

Fishman, R. 2003. "Urban Utopias: Ebenezer Howard, Frank Lloyd Wright, and Le Corbusier." In Readings in Planning Theory, edited by Scott Campbell and Susan S Fainstein, 21-60. $2^{\text {nd }}$ edition. Oxford: Blackwell Publishers.

Friedmann, J. 2011. Insurgencies: Essays in Planning Theory. New York, NY: Routledge. Gay, P. 1996. The Enlightenment: The Science of Freedom. New York, NY: W. W. Norton and Company.

Gibson-Graham, J.K., Cameron, J. and Healy, S. 2013. Take Back the Economy: An Ethical Guide for Transforming Our Communities Minneapolis: University of Minnesota Press.

Gleeson, B. and W. Steele. 2010. A Climate for Growth: Planning South East Queensland. Brisbane: UQ Press.

Gleeson, B. 2014. The Urban Condition. Abingdon: Oxon: Routledge

Harvey, D. 2001. Spaces of Capital: Towards A Critical Geography. New York: Routledge.

Healey, Patsy. 1993. "Planning Through Debate: The Communicative Turn In Planning Theory." In The Argumentative Turn in Policy Analysis and Planning, edited by Frank Fischer and John Forester, 233-253. Milton Park: Abingdon: Taylor and Francis.

Healey, P. 1997. Collaborative Planning. Vancouver: UBC Press. 
Healey, P. 2012. "The Universal and the Contingent: Some Reflections on the Transnational Flow of Planning Ideas and Practices.” Planning Theory 11 (1): 188-207.

Hope, Sally, and Timmel, A, eds. 2014. Training For Transformation in Practice. Bourton on Dunsmore, UK: Practical Action Publishing.

"Lessons from the Lock the Gate Movemen.t" Social Alternatives, Special Edition Community Climate Action, Vol 30, No. 1.

Ife, J. W. 2013. Community Development in an Uncertain World: Vision, Analysis and Practice. Port Melbourne, Vic: Cambridge University Press.

Israel, J. 2009. A Revolution of the Mind: Radical Enlightenment and the Intellectual Origins of Modern Democracy. Princeton, NJ: Princeton University Press.

Jacobs, J. 1964. The Death and Life of Great American Cities. Harmondsworth: Penguin Books.

Laszlo, E. 1996. The Systems View of the World: A Holistic Vision for Our Time. Cresskill, NJ: Hampton Press.

Lowe, I. 2010. “Climate Will Strangle Growth - If We Don’t!” In A Climate for Growth. Planning South-East Queensland, edited by B. Gleeson and W. Steele, 75-87. Brisbane: University of Queensland Press.

Mackay, H. 2013. The Good Life. Macmillan, Sydney.

Makau, Josina M., and Debian L. Marty. 2013. Dialogue and deliberation. Longrove, Illinois: Waveland Press.

Poon, J., K. Button, and P. Nijkamp. 2006. “Social Planning History: Scoping the Scene.” In Classics in Planning 1. Social Planning, edited by J. Poon, K. Button, and P. Nijkamp, 1-3. Cheltenham UK: Elgar. 
Putnam, R. (1993). “The Prosperous Community: Social Capital and Public Life.” American Prospect 13: 1-24.

Rose, Gillian. 1997. “Spatialities Of ‘Community', Power and Change: The Imagined Geographies of Community Arts Projects.” Cultural Studies 11 (1): 1-16.

Rose, Nikolas. 1999. Governing the Soul: The Shaping of the Private Self. 2nd ed. London:

Free Association Books.

Ruming, K., Gurran, N., Maggin, P., and Goodman, R. 2014. A national planning agenda? Unpacking the influence of federal urban policy on state planning reform, Australian Planner, 51, (2): 108-121.Sandercock, L. 2004. "Towards a Planning Imagination for the 21st Century." Journal of the American Planning Association 70, (2): 133-141.

Sandercock, L. 2012. “The Planner Tamed: Preparing Planners for the Twenty First Century.” Australian Planner 49 (4): 285-292.

Sandercock, L. and A. Forsyth. 1992. "A Gender Agenda. New Directions for Planning Theory." Journal of the American Planning Association 58: 49-59.

Sarkissian, W, N. Hofer, Y. Shore, S. Vajda, and C. Wilkinson. 2006. Kitchen Table Sustainability. Practical Recipes for Community Engagement with Sustainability. London: Earthscan.

Skolimowski, Henryk. 1994. The Participatory Mind: A New Theory of Knowledge and of the Universe. London: Arkana

Sharp, G (2010). From Dictatorship to Democracy: A Conceptual Framework for Liberation. 4th U.S. Ed. East Boston, MA: The Albert Einstein Institution.

Smith, G. 1996. "Ties, Nets and an Elastic Bund: Community in the Postmodern City." Community Development Journal 31 (3): 250-259. 
Steele, W. 2014. "Shifting Borders in a Climate of Change." In Planning across Borders in a Climate of Change, edited by W. Steele, T. Alizadeh, L. Eslami-Andargoli, and S. SerraoNeumann, 1-12. Oxon: Routledge.

Swain, C and Tait, M 2007, 'The Crisis of Trust and Planning', Planning Theory \& Practice, vol. 8 , no. 2 , pp. $229-247$.

The Queensland Plan. 2014. The Vision Statement.

http://queenslandplan.qld.gov.au/about/the-vision.aspx (accessed 4 August, 2014).

UN-HABITAT (2009) Global Report on Human Settlements 2009: Planning Sustainable Cities, UN-HABITAT and Earthscan.

UN-HABITAT (2011) Cities and Climate Change: Global Report on Human Settlements 2011, UN-HABITAT.

\footnotetext{
i The Group of 20 (or G20) is an international forum for governments from the major economies (representing $85 \%$ of the world's GDP), and central bank governors. It was established in 1999, and meets regularly to discuss matters of international coordination on economy policy. In November 2014 its meeting was held in Brisbane, Australia. ii In Queensland, the Sustainable Planning Act 2009 is being replaced by new planning legislation to be titled the Planning and Development Act. At the time of writing this article, the Draft Bill makes no reference to ecologically sustainable development.
} 